\title{
Two-incision versus Modified Watson-Jones Total Hip Arthroplasty in the Same Patients-- A Prospective Study of Clinical Outcomes and Patient Preferences
}

\author{
Chih-Chien Hu, MD; Jen-Suh Chern' ${ }^{1}$ PhD; Pang-Hsin Hsieh, MD; \\ Chun-Hsiung Shih ${ }^{2}$, MD; Steve WN Ueng, MD; Mel S. Lee, MD, PhD \\ Background: The two-incision technique and the modified Watson-Jones technique use \\ muscular intervals and avoid muscle cutting in total hip arthroplasty (THA). \\ However these two techniques have not been compared. \\ Methods: A prospective randomized study of clinical outcomes and patient preferences \\ was performed in 20 patients who had a two-incision THA in one hip and a \\ modified Watson-Jones THA in the other between January 2004 and August \\ 2007. The 20 patients were randomized equally to the two-incision first or \\ the modified Watson-Jones first group. After the second surgery, patients \\ were asked about their preferences for one of the two techniques and clinical \\ results were analyzed. \\ Results: After a minimal follow-up of 2 years, there were no differences in the hospi- \\ tal course, clinical results, functional outcomes, and radiographic results \\ between techniques. However more patients (70\%) preferred the two-inci- \\ sion side to the modified Watson-Jones side in the first 6 months regardless \\ which procedure was performed first. \\ Conclusion: Given the similarity of these two techniques in cup implantation and with \\ only a difference in femoral stem implantation, we think that the difference \\ in patient preferences in the early postoperative period might be related to \\ the surgical dissection and manipulation of the hip with the modified \\ Watson-Jones technique. \\ (Chang Gung Med J 2012;35:54-61)
}

Key words: minimally invasive total hip arthroplasty, two-incision approach, modified WatsonJones approach

$\mathrm{O}$ ver the past decade, minimally invasive total hip arthroplasty (THA) has attracted great attention and concern from patients and surgeons. Clinical studies with better results or inferior outcomes are controversially reported. ${ }^{(1-8)}$ Nevertheless, it is gener- ally agreed that by minimizing tissue trauma, patients may benefit from the techniques if the surgery is executed correctly.

There are many surgical techniques for minimally invasive THA. Some reduce the incision

From the Department of Orthopedics, Chang Gung Memorial Hospital at Linkou, Chang Gung University College of Medicine, Taoyuan, Taiwan; 'Department of Occupational Therapy \& Graduate institute of Clinical Behavioral Science, College of Medicine, Chang Gung University, Taoyuan, Taiwan; ${ }^{2}$ Department of Orthopedic Surgery, Chun-Shan Hospital, Taipei, Taiwan.

Received: Dec. 14, 2010; Accepted: Jul. 18, 2011

Correspondence to: Dr. Mel S. Lee, Department of Orthopedic Surgery, Chang Gung Memorial Hospital at Linkou. 5, Fusing St., Gueishan Township, Taoyuan County 333, Taiwan (R.O.C.) Tel: 886-3-3281200 ext. 2420; Fax: 886-3-3278113;

E-mail: bone@doctor.com 
length and muscle cutting ${ }^{(3,7,9-12)}$ and others use intermuscular intervals to avoid muscle sectioning. ${ }^{(1,2,4,8,13)}$ There is a major dichotomy of opinion between surgeons, referring practitioners, and patients regarding a successful arthroplasty. ${ }^{(14-16)}$ While patients may consider minimally invasive surgery (MIS) as a new technology that can increase satisfaction, surgeons are more concerned about the risks, clinical outcomes, and complications. Comparative studies of a posterior approach, ${ }^{(7,9,16-19)}$ transgluteal approach, ${ }^{(1,12,20)}$ two-incision technique, ${ }^{(21)}$ and different routes ${ }^{(22)}$ have been reported. Similar to the two-incision technique, the modified Watson-Jones technique avoids muscle cutting and uses the intermuscular interval between the gluteus medius and tensor fascia latae for both cup and stem implantation. ${ }^{(13,23)}$ However, these two techniques have not been compared in the literature. The purpose of this prospective randomized study was to compare the hospital course, surgical results, clinical outcomes, and patient preferences in patients who had a two-incision THA in one hip and a modified Watson-Jones THA in the other.

\section{METHODS}

Between January 2004 and August 2007, 151 two-incision THAs in 143 patients and 225 modified Watson-Jones THAs in 198 patients were performed by a single surgeon. Among them, 40 patients who had bilateral hip involvement were eligible for study enrollment. During the study period of time, 9 patients chose to have the same minimally invasive approach for their bilateral hips and 11 patients who were eligible chose not to be enrolled in the study. After 20 patients (40 hips) consented and completed the surgery, enrollment was stopped (Fig. 1). They were equally randomized into the two-incision first or modified Watson-Jones first group and followed regularly. The inclusion criteria were patients who had bilateral hip disease scheduled for sequential bilateral primary THA. The operations were performed by a single surgeon who learned the techniques through cadaver workshops and live surgeries with the developer of the modified Watson-Jones technique. The minimal time interval between the two THAs was 3 months to allow recovery from the previous surgery and to avoid recall bias. The exclusion criteria included previous hip surgeries, simultaneous bilateral THAs, sequential bilateral THAs performed within 3 months, pathological conditions that were contraindicated for the minimally invasive approach, and any complications that confounded the surgical results.

\section{Treatment protocol}

The patients were scheduled for surgery on the side with more discomfort first and the choice of surgical approach was randomly assigned. The time for the second THA was not predetermined and a minimal 3 months was required for inclusion in the study.

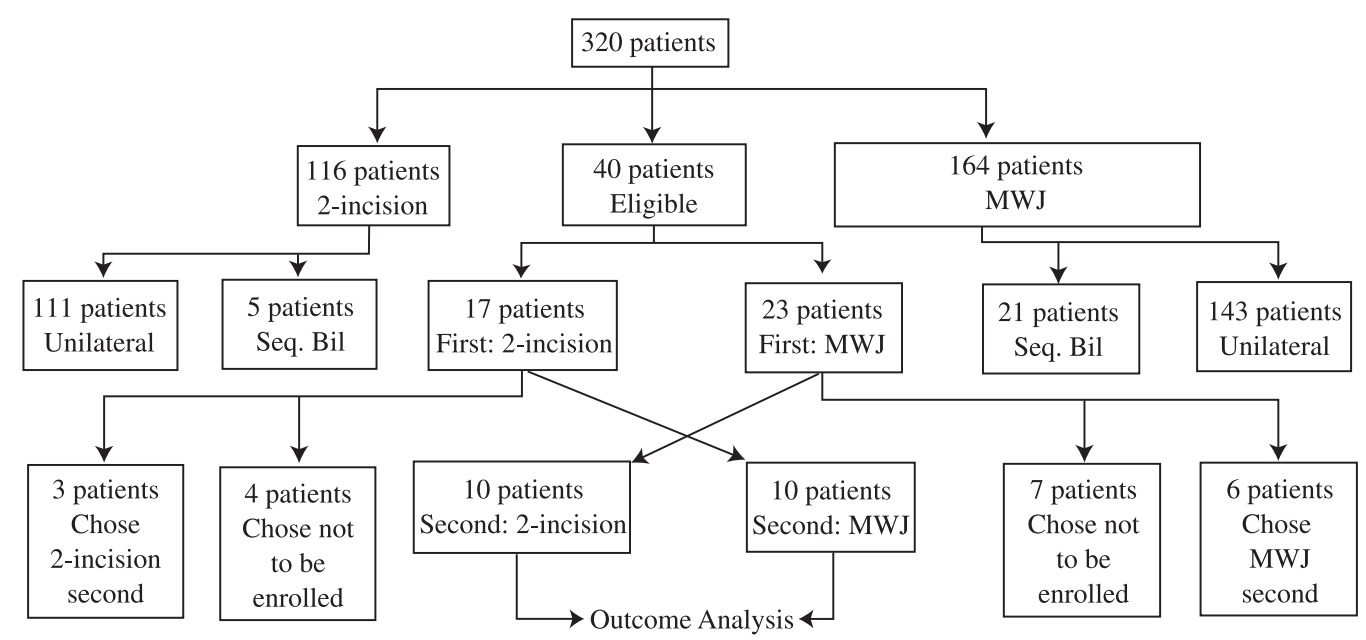

Fig. 1 Patient Enrollment Flow Chart. Seq. Abbreviations used: Bil: Sequential Bilateral; MWJ: modified Watson-Jones technique. 
In the two-incision first group, the average time interval to the modified Watson-Jones THA was 9.7 months (range, 3 to 19 months). In the modified Watson-Jones first group, the average time interval to the two-incision THA was 5.9 months (range, 3 to 13 months).

All patients received general anesthesia. All patients had the same postoperative analgesic protocol with intramuscular meperidine $(50 \mathrm{mg})$ injections every four hours and oral acetaminophen $500 \mathrm{mg}$ plus tramadol $50 \mathrm{mg}$ every six hours. Data on gender, age, body mass index, preoperative diagnosis and length of hospital stay were recorded.

\section{Surgical techniques}

For the two-incision THA, the patient was positioned in a lateral position as described by Lee et al. ${ }^{(23)}$ Dissection was carried out between the sartorius and tensor fasciae latae superficially and between the gluteus medius and rectus femoris underneath. A special acetabular reamer and cup inserter were used for the acetabular side from the anterior wound. Another posterior incision was made through the gluteus maximus superficially and between the piriformis and gluteus medius underneath for femoral preparation. The femoral canal was prepared with a rasp and reamer. For the modified Watson-Jones THA, the patient was positioned in the lateral position on a special operating table in which one foot piece could be removed to facilitate hyperextension, external rotation, and adduction of the hip. The surgical procedure was followed the steps described by
Bertin and Röttinger. ${ }^{(13)}$ Dissection was carried out between the tensor fasciae latae and the gluteus medius. A special acetabular reamer and cup inserter were used. On the femoral side, a special dog-legged broach handle and curved retractors were used. A Trilogy cup (Zimmer, Warsaw, Indiana, U.S.A.) and Fiber Metal Taper stem (Versys; Zimmer, Warsaw, Indiana) were used in all hips with a cementless press-fitting technique.

The time in the operating room, perioperative blood loss, total incision length, and any difficulties during surgeries were recorded.

\section{Radiographic evaluation}

Radiographs were taken immediately postoperatively and at intervals of 3 months, 6 months, and yearly after the surgery. The cup inclination angle, anteversion angle, stem alignment, and canal filling ratio were recorded. ${ }^{(23)}$ Any migration, loosening, or early failure of the components was recorded.

\section{Functional results and patient preferences}

Functional evaluations were assessed with the Harris hip score (HHS) preoperatively and at intervals of 6 weeks, 3 months, 6 months, and yearly after the surgery. ${ }^{(24)}$ A rehabilitation protocol with early ambulation under protective weight bearing for 6 weeks was used in both groups of patients. Patient preferences were assessed after the second THA during the hospitalization period and at 6 weeks, 3 months, 6 months, 1 year, and 2 years of follow-up (Table 1).

Table 1. Patient Preference after Two-incision and Modified Watson-Jones THA

Patient ID:

Assessment time: $\bigcirc$ PostOP $\bigcirc 6$ wks $\bigcirc 3 \mathrm{~m} \quad \bigcirc 6 \mathrm{~m} \bigcirc 1 \mathrm{y} \bigcirc 2 \mathrm{y}$

1. Do you prefer the results of one of your THA more than the other?

( ) Yes ( ) No

2. If yes, please designate a point on the scale to indicate how much you prefer one side to the other side.

Prefer

Prefer

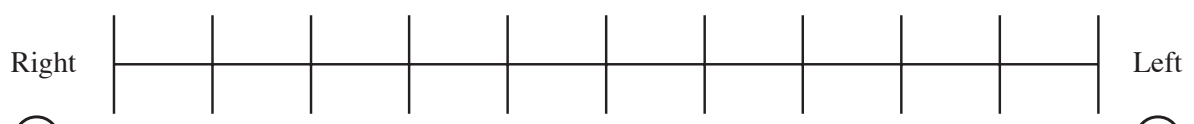

(ن)

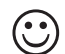

Note: relative preference $=(10-\mathrm{x}) . \mathrm{x}=$ distance from the point designated to the side of the scale. 


\section{Statistical analysis}

Statistical analysis was done using Wilcoxon signed-rank test and the chi-square test. All statistical analysis was performed using SPSS 17.0 for Windows (SPSS Inc., Chicago, IL, U.S.A.).

\section{RESULTS}

The two-incision THA resulted in a longer operation time (137 minutes vs. 124 minutes), more blood loss (608 mL vs. $473 \mathrm{~mL})$, a longer incision length $(9.8 \mathrm{~cm}$ vs. $9.1 \mathrm{~cm})$, and longer hospital stay (5.4 days vs. 4.7 days) compared with the modified Watson-Jones THA. However the differences were not statistically significantly different except for the hospital stay $(p=0.04)$ (Table 2$)$. The preoperative

Table 2. Patient Data and Clinical Outcomes of Two-incision and Modified Watson-Jones Total Hip Arthroplasty

\begin{tabular}{|c|c|c|c|}
\hline & Two-incision & $\begin{array}{c}\text { Modifie } \\
\text { Watson-Jones }\end{array}$ & $p$-value \\
\hline No. of hips & 20 & 20 & \\
\hline Age (years) & $\begin{array}{c}51.6 \pm 14.5 \\
(29 \text { to } 79)\end{array}$ & $\begin{array}{c}52.1 \pm 14.9 \\
(29 \text { to } 82)\end{array}$ & 0.06 \\
\hline Body mass index & $\begin{array}{c}24.3 \pm 5 \\
(17.8 \text { to } 38)\end{array}$ & $\begin{array}{c}24.4 \pm 5 \\
(17 \text { to } 37.2)\end{array}$ & 0.31 \\
\hline Operation time (min) & $\begin{array}{c}137 \pm 36 \\
(80 \text { to } 210)\end{array}$ & $\begin{array}{l}124 \pm 32 \\
(63 \text { to } 191)\end{array}$ & 0.11 \\
\hline Blood loss (mL) & $\begin{array}{c}608 \pm 238 \\
(150 \text { to } 1400)\end{array}$ & $\begin{array}{c}473 \pm 215 \\
(200 \text { to } 900)\end{array}$ & 0.06 \\
\hline Wound length $(\mathrm{cm})$ & $\begin{array}{c}9.8 \pm 1.4 \\
(8 \text { to } 12)\end{array}$ & $\begin{array}{l}9.1 \pm 1.3 \\
(6.5 \text { to } 12)\end{array}$ & 0.11 \\
\hline Hospital stay (days) & $\begin{array}{c}5.4 \pm 1.3 \\
(4 \text { to } 9)\end{array}$ & $\begin{array}{c}4.7 \pm 1.6 \\
(3 \text { to } 9)\end{array}$ & 0.04 \\
\hline \multicolumn{4}{|l|}{ Harris hip score } \\
\hline Preoperative & $60 \pm 12$ & $65 \pm 14$ & 0.09 \\
\hline 6 weeks & $90 \pm 6$ & $91 \pm 6$ & 0.98 \\
\hline 3 months & $94 \pm 5$ & $94 \pm 5$ & 0.96 \\
\hline 6 months & $96 \pm 4$ & $96 \pm 4$ & 0.93 \\
\hline 1 year & $98 \pm 3$ & $97 \pm 4$ & 0.86 \\
\hline 2 years & $97 \pm 5$ & $97 \pm 3$ & 0.36 \\
\hline
\end{tabular}

Data are presented as mean \pm standard deviation (range). Statistical analysis was done using the Wilcoxon signed-rank tests.
HSS was $60 \pm 12$ points in the two-incision THA hips and $65 \pm 14$ points in the modified WatsonJones THA hips. Both groups of hips showed rapid recovery without differences in the HHS at each interval of follow-up. No complications such as pulmonary embolism, fractures, dislocations, or infections were noted immediately postoperatively or in the follow-up. At the last follow-up, all hips showed good bone incorporation without evidence of radiographic or clinical loosening. The radiographic results were not different between the two techniques (Table 3).

Although there were no differences in the hospital course, clinical results, functional outcomes, and radiographic results for the two techniques, there were differences in patient preferences. The twoincision side was preferred by $70 \%$ of patients regardless of which technique was performed first $(p$ $=0.005$ immediately postoperative and $p=0.006$ at six weeks follow-up). The subjective preference on the two-incision side decreased to $65 \%$ (5\% responded no difference) at 3 months $(p=0.008)$ and $30 \%$ (65\% responded no difference) at 6 months ( $p=$ 0.025 ). Accordingly, the relative preference for either hip in the same patient was also demonstrated by the point designated by the patient on a scale (Fig. 2). It was found the relative preference for the two-incision side was higher until 6 months and was not different thereafter.

Table 3. Radiographic Results of Two-incision and Modified Watson-Jones Total Hip Arthroplasty

\begin{tabular}{|c|c|c|c|}
\hline & Two-incision & $\begin{array}{c}\text { Modified } \\
\text { Watson-Jones }\end{array}$ & $p$-value \\
\hline Cup inclination $\left({ }^{\circ}\right)$ & $\begin{array}{l}44.5 \pm 5.9 \\
(30.5 \text { to } 55)\end{array}$ & $\begin{array}{c}44.8 \pm 6 \\
(35.2 \text { to } 57)\end{array}$ & 0.81 \\
\hline Cup anteversion $\left({ }^{\circ}\right)$ & $\begin{array}{c}15.2 \pm 7.8 \\
(0 \text { to } 30)\end{array}$ & $\begin{array}{c}12.9 \pm 8.2 \\
(0 \text { to } 28)\end{array}$ & 0.42 \\
\hline Stem alignment $\left({ }^{\circ}\right)$ & $\begin{array}{c}0.1 \pm 0.6 \\
(-0.8 \text { to } 2.4)\end{array}$ & $\begin{array}{l}0.1 \pm 1 \\
(-3 \text { to } 2)\end{array}$ & 0.96 \\
\hline Canal fill ratio (\%) & $\begin{array}{c}93 \pm 3 \\
\text { (88 to } 99)\end{array}$ & $\begin{array}{c}90 \pm 6 \\
\text { (80 to } 100)\end{array}$ & 0.08 \\
\hline
\end{tabular}

Data are presented as mean \pm standard deviation (range). Statistical analysis was done using the Wilcoxon signed-rank Test. 


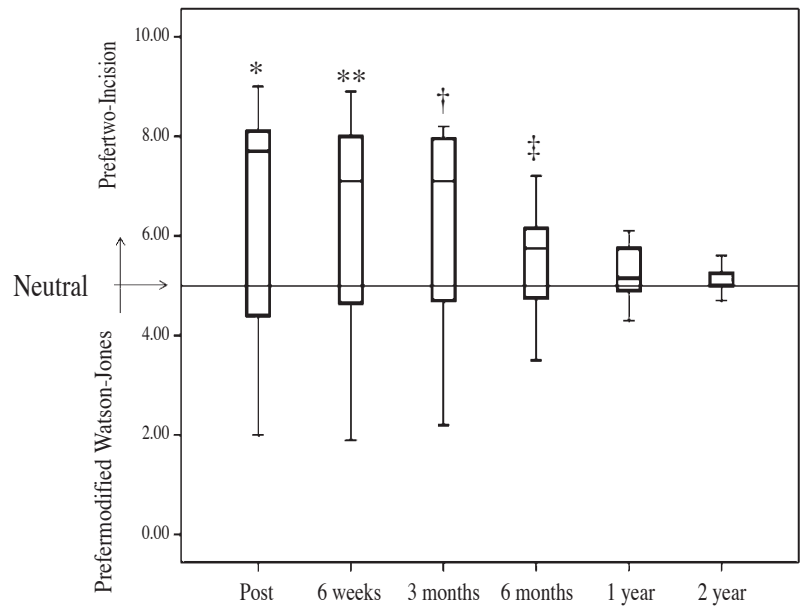

Fig. 2 Preference score for the two-incision and modified Watson-Jones THAs in the same patient. The box and whisker plot represents the upper quartile, lower quartile and median preference score. Statistical analysis was done using the Wilcoxon signed-rank Test. (*: $p=0.005 ; * *: p=0.006 ; \uparrow: p$ $=0.008 ;$ : $p=0.025$ ).

\section{DISCUSSION}

Minimally invasive THA has provoked controversy and attracted great attention in the past decade. The techniques, in general, can be divided into two categories. Some use abridged incisions such as a transgluteal ${ }^{(11,12,20)}$ or a posterolateral ${ }^{(7,9,16-19)}$ route, while others ${ }^{(1,2,4,13,21,23)}$ avoid muscle cutting by using intermuscular intervals for surgery. Retrospective comparative studies of the two-incision technique have reported only modest outcomes and potentially higher complication rates compared with the transgluteal ${ }^{(8)}$ and posterior techniques. ${ }^{(21,22)}$ In contrast, favorable results have been reported with the modified Watson-Jones technique ${ }^{(13,27,28)}$ which uses the intermuscular interval between the tensor fascia latae and gluteus medius for both cup and stem implantation. There has been no study comparing the modified Watson-Jones and two-incision techniques in the literature. In this study, the hospital course, surgical results, and clinical outcomes of the two-incision and modified Watson-Jones THAs were compared in the same patient. A comparison of the results in the same patient eliminates individual variability and provides a chance to explore patient preferences. Good surgical results and clinical outcomes were obtained for both techniques as long as they were conducted adequately. After the completion of the study, all patients responded that they were satisfied with the results and happy to be enrolled in this study. Theoretically, both techniques spare muscle cutting and preserve soft tissues around the hip that render optimal recovery. However it was noted that more patients preferred the two-incision side to the modified Watson-Jones side in the early postoperative period. Recall bias was not considered a confounding factor because patients were equally randomized into groups. In addition, the intervals between the two THAs were 9.7 months and 5.9 months, respectively. We think that the differences might be techniquerelated. In preparing the acetabulum for cup implantation, both techniques are similar with the only difference in the different intermuscular intervals used for surgery. For the femoral stem implantation, the two techniques are different. The modified WatsonJones technique requires release of the posterior hip capsule and sometimes the piriformis tendon to facilitate external rotation, hyperextension, and adduction of the hip for femoral broaching and stem implantation. In contrast, the two-incision technique requires less manipulation and only the interval between the piriformis and gluteus medius is used for femoral broaching and stem implantation. Although the difference in the preference might be clinically inconsequential, since it was only noted in the early postoperative period, and all patients were satisfied with their clinical outcomes at the most recent follow-up, it is still of interest to discover evidence to identify objectively the risks and benefits of each MIS technique, especially from the patient's perspective.

In the literature, the posterior approach is the most commonly reported technique in case series or as a comparison to a standard approach..$^{(7,9,16-19)}$ The two-incision approach has been less addressed and controversial outcomes have been reported. ${ }^{(1,2,6,8,21,22,26)}$ In the learning period or in inexperienced hands, complication rates are significantly higher with the two-incision technique compared with other conventional methods. ${ }^{(8,21,26)}$ Over the past years, the enthusiasm about the minimally invasive THA seems to have gradually decreased because of a lack of high quality prospective randomized studies, and sustained superior functional outcomes following the approaches have not been documented conclusively. ${ }^{(29,30)}$ Nevertheless more surgeons are adopting 
some type of minimally invasive THA in their practice because of pressure from patients, institutions, industries, and peers. ${ }^{(3,14,15,25)}$ In this study, we found the surgical results, hospital course, and functional outcomes were comparable in the two-incision technique and the modified Watson-Jones technique. We also noted more patients $(70 \%)$ preferred the twoincision side to the modified Watson-Jones side in the first 6 months, regardless of which procedure was performed first. The strengths of this study include the prospective randomized study design, standardized surgical techniques performed by a single surgeon, and comparison of two similar techniques using the same patient to eliminate selection bias. However this study was limited by the small number of patients, and the risks and benefits of the two techniques could not be objectively assessed because only successful cases were included. Nevertheless, this study provides information about two similar THA techniques from the patient's perspective, which has not been explored before. However, randomized clinical trials with high levels of evidence are needed to determine the merits of these two and other techniques, to objectively analyze long term clinical outcomes, and to meet patient requests.

\section{REFERENCES}

1. Berger RA. Total hip arthroplasty using the minimally invasive two-incision approach. Clin Orthop 2003;417: 232-41.

2. Berger RA, Jacobs JJ, Meneghini RM, Valle CD, Paprosky W, Rosenberg AG. Rapid rehabilitation and recovery with minimally invasive total hip arthroplasty. Clin Orthop 2004;429:239-47.

3. Berry DJ, Berger RA, Callaghan JJ, Dorr LD, Duwelius PJ, Hartzband MA, Lieberman JR, Mears DC. American orthopaedic association symposium: minimally invasive total hip arthroplasty. Development, early results, and a critical analysis. J Bone Joint Surg Am 2003;85:2235-46.

4. Kennon RE, Keggi JM, Wetmore RS, Zatorski LE, Huo $\mathrm{MH}$, Keggi KJ. Total hip arthroplasty through a minimally invasive anterior surgical approach. J Bone Joint Surg Am 2003;85:39-48.

5. Fehring TK, Mason JB. Catastrophic complications of minimally invasive hip surgery. A series of three cases. J Bone Joint Surg Am 2005;87:711-4.

6. Feinblatt JS, Berend KR, Lombardi AV Jr. Severe symptomatic hetertopic ossification and dislocation: a complication after two-incision minimally invasive total hip arthroplasty. J Arthroplasty 2005;20:802-6.

7. Ogonda L, Wilson R, Archbold P, Lawlor M, Humphreys P, O'Brien S, Beverland D. A minimal-incision technique in total hip arthroplasty does not improve early postoperative outcomes. A prospective, randomized, controlled trial. J Bone Joint Surg Am 2005;87:701-10.

8. Bal BS, Haltom D, Aleto T, Barrett M. Early complications of primary total hip replacement performed with a two-incision minimally invasive technique. J Bone Joint Surg Am 2005;87:2432-8.

9. Wright JM, Crockett HC, Delgado S, Lyman S, Madsen M, Sculco TP. Mini-incision for total hip arthroplasty. A prospective, controlled investigation with 5-year followup evaluation. J Arthroplasty 2004;19:538-45.

10. Goldstein WM, Branson JJ, Berland KA, Gordon AC. Minimal-incision total hip arthroplasty. J Bone Joint Surg Am 2003;85:33-8.

11. Frndak PA, Mallory TH, Lombardi AV Jr. Translateral surgical approach to the hip: The abductor muscle "split". Clin Orthop 1993;295:135-41.

12. Siguier T, Siguier M, Brumpt B. Mini-incision anterior approach does not increase dislocation rate. A study of 1037 total hip replacements. Clin Orthop 2004;426:16473.

13. Bertin KC, Röttinger H. Anterolateral mini-incision hip replacement surgery. A modified Watson-Jones approach. Clin Orthop 2004;429:248-55.

14. Stürmer T, Dreihhöfer, Gröber-Grätz D, Brenner H, Dieppe P, Puhl W, Günther KP. Differences in the views of orthopaedic surgeons and referring practitioners on the determinants of outcome after total hip replacement. J Bone Joint Surg Br 2005;87:1416-9.

15. Parvizi J, Sharkey PF, Pour AE, Rapuri V, Hozack WJ, Rothman RH. Hip arthroplasty with minimally invasive surgery. A survey comparing the opinion of highly qualified experts vs patients. J Arthroplasty 2006;21:S38-46.

16. Dorr LD, Thomas D, Long WT, Polatin PB, Sirianni LE. Psychologic reasons for patients preferring minimally invasive total hip arthroplasty. Clin Orthop 2007;458:94100.

17. Kim YH. Comparison of primary total hip arthroplasties performed with a minimally invasive technique or a standard technique. A prospective and randomized study. J Arthroplasty 2006;21:1092-8.

18. Bennett D, Ogonda L, Elliott D, Humphreys L, Lawlor M, Beverland D. Comparison of immediate postoperative walking ability in patients receiving minimally invasive and standard-incision hip arthroplasty. A prospective blinded study. J Arthroplasty 2007;22:490-5.

19. Dorr LD, Maheshwari AV, Long WT, Wan Z, Sirianni LE. Early pain relief and function after posterior minimally invasive and conventional total hip arthroplasty. A prospective, randomized, blinded study. J Bone Joint Surg Am 2007;89:1153-60.

20. Ciminiello M, Parvizi J, Sharkey PF, Eslampour A, 
Rothman RH. Total hip arthroplasty. Is small incision better? J Arthroplasty 2006;21:484-8.

21. Pagnano MW, Leone J, Lewallen DG, Hanssen AD. Twoincision THA had modest outcomes and some substantial complications. Clin Orthop 2005;441:86-90.

22. Duwelius PJ, Burknart RL, Hayhurst JO, Moller H, Butler JBV. Comparision of the 2-incision and mini-incision posterior total hip arthroplasty technique. A retrospective match-pair controlled study. J Arthroplasty 2007;22:4856.

23. Lee MS, Kuo CH, Senan V, Chen WJ, Chen LH, Ueng SWN. Two-incision total hip replacement: Intraoperative fluoroscopy versus imageless navigation. Hip Int 2006;16:S35-41.

24. Harris WH. Traumatic arthritis of the hip after dislocation and acetabular fractures: treatment by mold arthroplasty. An end-result study using a new method of result evaluation. J Bone Joint Surg Am 1969;51:737-55.

25. Klein, Gregg R. Parvizi, Javad. Sharkey, Peter F.
Rothman, Richard H. Hozack, William J. Minimally invasive total hip arthroplasty: internet claims made by members of the Hip Society. Clin Orthop 2005;441:68-70.

26. Rosenberg, Aaron G. A two-incision approach: promises and pitfalls. Orthopedics 2005;28:935-6.

27. Jerosch J, Theising C, Fadel ME. Antero-lateral minimal invasive (ALMI) approach for total hip arthroplasty technique and early results. Arch Orthop Trauma Surg 2006;126:164-73.

28. Laffosse JM, Chiron P, Molinier F, Bensafi H, Puget J. Prospective and comparative study of the anterolateral mini-invasive approach versus minimally invasive posterior approach for primary total hip replacement. Early results. Int Orthop 2007;31:597-603.

29. Huo MH, Parvizi J, Bal S, Mont MA. What's new in total hip arthroplasty. J Bone Joint Surg Am 2008;90:2043-55.

30. Wall SJ, Mears SC. Analysis of published evidence on minimally invasive total hip arthroplasty. J Arthroplasty 2008;23:S55-8. 


\title{
探討同一位病人一側接受雙刀口另一側接受改良式 華生瓊斯人工髖關節置換手術對臨床成效以及病人喜好的影響
}

\author{
胡志堅 陳貞夙 ${ }^{1}$ 謝邦釒金 施俊雄 $^{2}$ 翁文能 李炫昇
}

背 景: 雙刀口與改良式華生瓊斯人工䯣關節置換手術都是以組織間吵避免肌肉切開來進 行。然而在過去的文獻, 這兩種手術方法從來没有互相比較過。

方 法: 從 2004 年 1 月到 2007 年 8 月, 我們前瞻性的以隨機分配在 20 位兩側䯘關節都需要 接受人工髖關節置換的病人, 一側以隻刀口、另一側以改良式華生瓊斯方式進行人 工髀關節手術。在第二側手術後, 我們以問卷詢問病人對於手術的喜好, 同時觀察 雨種手術的臨床成效。

結 果: 在至少兩年以上的臨床追蹤, 我們發現即使在住院過程、臨床結果、功能恢復、以 及 $\mathrm{X}$ 光追蹤檢查, 雨種手術都能達到理想的結果, 但是在病人的滿意度方面則發 現, 不論是先接受隻刀口手術或先接受改良式華生瑍斯手術, 有百分之七十的病人 在手術後六個月仍然表示比較喜歡隻刀口手術的那一側。

結 論：由於這兩種人工髂關節手術的方法相當類似, 只是利用不同的組織間纱施行髀白杯 與股骨柄的植入, 我們推測病人手術後喜好程度的不同可能與改良式華生瓊斯手術 法的手術操作過程有關。

(長庚醫誌 2012;35:54-61)

關鍵詞：微創人工髋關節手術, 隻刀口手術, 改良式華生瓊斯手術法

長庚醫療財團法人林口長庚紀念醫院 骨科部; 長庚大學 醫學院 職治物治系及臨床行爲科學研究所; ;台北中山醫院 骨 科

受文日期 : 民國99年12月14日 ; 接受刊載 : 民國100年7月18日

通訊作者 : 李炫昇醫師, 長庚醫療財團法人林口長庚紀念醫院 骨科部。桃園縣333龜山郷復興街5號。

Tel: (03)3281200轉2420; Fax: (03)3278113; E-mail: bone@doctor.com 